\title{
NOTES.
}

\section{CORRELATION OF GROWTH UNDER THE INFLUENCE} OF INJURIFS. - In the paper on this subject which appeared in the Annals of Botany, Vol. xi, No. XLIV, December, I 897, reference was made on p. 5I3 to Laurent's valuable paper, Études sur la Turgescence chez le Phycomyces, but by an oversight the name of the author was omitted.

\section{O. TOWNSEND.}

GELATINE AS A FIXATIVE.-Microtome-sections passing through embryonic and parenchymatous tissues embedded in paraffin are sufficiently fixed to the microscope-slide, for staining purposes, by their own simple adhesion to the glass. This, however, is not the case when the section comprises a large proportion of woody tissue. For such preparations, collodion, agar-agar, and albumen have been recommended as fixatives. The first of these, so far as my experience extends, is the most certain. But it has the disadvantage that with its use the paraffin-section cannot be floated out on water on the slip and caused to flatten out by gentle warmth. The same objection applies to albumen ${ }^{1}$, and in addition, I have found it to be very easily coloured by stains (especially the blue dyes) which are often essential to use in microscopic work. I have no experience with agar-agar, but Zimmermann states that it becomes dyed with haematoxylinone of the most important stains, and that the sections often come loose from the glass during the staining and washing manipulations. This latter objection, perhaps the most vexatious of all, applies, to some extent, to albumen also.

Recently I have used as a fixative a dilute solution of gelatine in a watery solution of bichromate of potash. The solution should be quite fluid at $10^{\circ} \mathrm{C}$. In use the ribbon of paraffin-sections is laid on a drop of this solution on the slide. Wrinkles in the sections may

\footnotetext{
1 I used the preparation given by Zimmermann, Bot. Mikrotech.
} 


\section{$2 \mathrm{BHL}$ Biodiversity Heritage Library}

Townsend, Charles Orvin. 1898. "Correlation of growth under the influence of injuries." Annals of botany 12, 117-117.

https://doi.org/10.1093/oxfordjournals.aob.a088680.

View This Item Online: https://www.biodiversitylibrary.org/item/233102

DOI: https://doi.org/10.1093/oxfordjournals.aob.a088680

Permalink: https://www.biodiversitylibrary.org/partpdf/318495

\section{Holding Institution}

Smithsonian Libraries

\section{Sponsored by}

Biodiversity Heritage Library

\section{Copyright \& Reuse}

Copyright Status: Not in copyright. The BHL knows of no copyright restrictions on this item.

This document was created from content at the Biodiversity Heritage Library, the world's largest open access digital library for biodiversity literature and archives. Visit BHL at https://www.biodiversitylibrary.org. 